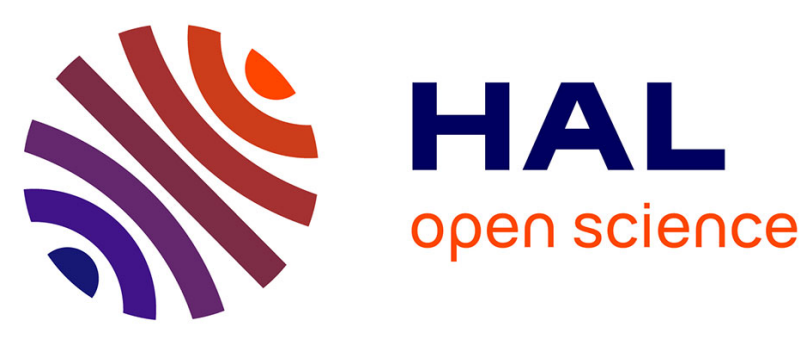

\title{
Species- and tissue-dependent effects of NO and cyclic GMP on cardiac ion channels
}

\author{
Rodolphe Fischmeister, Liliana Castro, Aniella Abi-Gerges, Francesca \\ Rochais, Grégoire Vandecasteele
}

\section{- To cite this version:}

Rodolphe Fischmeister, Liliana Castro, Aniella Abi-Gerges, Francesca Rochais, Grégoire Vandecasteele. Species- and tissue-dependent effects of NO and cyclic GMP on cardiac ion channels. Comparative Biochemistry and Physiology Part A: Molecular \& Integrative Physiology, 2005, 142 (2), pp.136-143. 10.1016/j.cbpb.2005.04.012 . hal-03161409

\section{HAL Id: hal-03161409 \\ https://hal.science/hal-03161409}

Submitted on 6 Mar 2021

HAL is a multi-disciplinary open access archive for the deposit and dissemination of scientific research documents, whether they are published or not. The documents may come from teaching and research institutions in France or abroad, or from public or private research centers.
L'archive ouverte pluridisciplinaire HAL, est destinée au dépôt et à la diffusion de documents scientifiques de niveau recherche, publiés ou non, émanant des établissements d'enseignement et de recherche français ou étrangers, des laboratoires publics ou privés. 


\title{
Species- and tissue-dependent effects of NO and cyclic GMP on cardiac ion channels
}

\author{
Rodolphe Fischmeister, Liliana Castro, Aniella Abi-Gerges, Francesca Rochais, \\ Grégoire Vandecasteele
}

INSERM U-446, Laboratoire de Cardiologie Cellulaire et Moléculaire, Faculté de Pharmacie, Université Paris-Sud, F-92296 Châtenay-Malabry, France

Address for correspondence:

Rodolphe FISCHMEISTER

INSERM U-446

Faculté de Pharmacie

5, Rue J.-B. Clément

F-92296 Châtenay-Malabry Cedex

France

Tel. +33-1-46 835757

Fax +33-1-46 835475

E-mail: fisch@vjf.inserm.fr 


\section{ABSTRACT}

Biochemical studies have established the presence of a NO pathway in the heart, including sources of NO and various effectors. Several cardiac ion channels have been shown to be modified by NO, such as L-type $\mathrm{Ca}^{2+}$, ATP-sensitive $\mathrm{K}^{+}$, and pacemaker $f$-channels. Some of these effects are mediated by cGMP, through the activity of three main proteins: the cGMPdependent protein kinase (PKG), the cGMP-stimulated phosphodiesterase (PDE2) and the cGMP-inhibited PDE (PDE3). Other effects appear independent of cGMP, as for instance the NO modulation of the ryanodine receptor- $\mathrm{Ca}^{2+}$ channel. In the case of the cardiac L-type $\mathrm{Ca}^{2+}$ channel current $\left(\mathrm{I}_{\mathrm{Ca}, \mathrm{L}}\right)$, both cGMP-dependent and cGMP-independent effects have been reported, with important tissue and species specificity. For instance, in rabbit sinoatrial myocytes, NO inhibits the $\beta$-adrenergic stimulation of $\mathrm{I}_{\mathrm{Ca}, \mathrm{L}}$ through activation of PDE2. In cat and human atrial myocytes, NO potentiates the cAMP-dependent stimulation of $\mathrm{I}_{\mathrm{Ca}, \mathrm{L}}$ through inhibition of PDE3. In rabbit atrial myocytes, NO enhances $\mathrm{I}_{\mathrm{Ca}, \mathrm{L}}$ in a cAMP-independent manner through the activation of PKG. In ventricular myocytes, NO exerts opposite effects on $\mathrm{I}_{\mathrm{Ca}, \mathrm{L}}$ : an inhibition mediated by PKG in mammalian myocytes but by PDE2 in frog myocytes; a stimulation attributed to PDE3 inhibition in frog ventricular myocytes but to a direct effect of NO in ferret ventricular myocytes. Finally, NO can also regulate cardiac ion channels by a direct action on G-proteins and adenylyl cyclase.

Key words: cGMP - nitric oxide - cardiac tissue - ion channels - cAMP - cyclic nucleotide phosphodiesterases - cGMP-dependent protein kinase - L-type calcium current 


\section{INTRODUCTION}

The cyclic nucleotides cAMP and cGMP participate in the main regulations of cardiac function. They act as second messengers for sympathetic and parasympathetic systems, nitric oxide (NO) and natriuretic peptides. Noradrenaline released from sympathetic nerve terminals binds to $\beta$-adrenergic receptors ( $\beta$-ARs) coupled to Gs which activate cAMP synthesis by adenylyl cyclases. Classically, cardiac effects of cAMP are attributed to phosphorylation by cAMP-dependent protein kinase (PKA) of several proteins critically involved in excitationcontraction coupling, including the L-type $\mathrm{Ca}^{2+}$ channels (which underlies the L-type $\mathrm{Ca}^{2+}$ current, $\left.\mathrm{I}_{\mathrm{Ca}, \mathrm{L}}\right)$, phospholamban, ryanodine receptor and several contractile proteins (Rapundalo 1998; Bers 2002). PKA also activates the cAMP response element-binding protein (CREB) family of transcription factors (Muller et al. 2001). Other cAMP targets in the heart include the exchange protein directly activated by cAMP (Epac) and $f$-channels (AbiGerges et al. 2000; Sartiani et al. 2002; Robinson and Siegelbaum 2003). Acute increase in cAMP has chronotropic, inotropic and lusitropic effects, which are counteracted by acetylcholine (ACh) released from sympathetic nerves. ACh binds to muscarinic M2 receptors which inhibit cAMP synthesis through pertussis toxin sensitive Gi proteins (Méry et al. 1997; Harvey and Belevych 2003). While an acute stimulation of the cAMP pathway is beneficial for the heart, a sustained activation, as occurs for instance in transgenic mice with cardiac overexpression of $\beta 1$-ARs (Engelhardt et al. 1999) or Gs (Iwase et al. 1996) leads to hypertrophic growth, ventricular dysfunction and, ultimately, to heart failure (Port and Bristow 2001). A similar situation is found in different forms of human chronic heart failure, which are all associated with elevated catecholamines (Swynghedauw 2004). 
cGMP is often represented as the mirror of cAMP. In the short term, cGMP opposes the positive effects of cAMP on cardiac function (Fischmeister and Méry 1996), and is sometimes considered as the second messenger involved in parasympathetic regulation of the heart (Massion et al. 2003). Intracardiac cGMP production is due to two different forms of guanylyl cyclases (GC): the soluble GC (sGC), which is activated by NO, and the particulate GC (pGC), which is activated by natriuretic peptides (NPs) ANP, BNP and CNP. NO is produced by cardiac myocytes and endothelial cells nearby, and two NO-synthases (NOS), endothelial (eNOS) and neuronal (nNOS), coexist in cardiac myocytes (Massion et al. 2003; Damy et al. 2004). A third, inducible form (iNOS) is expressed in pathological conditions such as septic shock (Abi-Gerges et al. 1999) or heart failure (Massion et al. 2003; Paulus and Bronzwaer 2004). Upon NO or NP action, cGMP accumulates and interacts with several targets, such as cGMP-dependent protein kinase (PKG) and phosphodiesterases (PDEs), which attenuate the $\beta$-adrenergic response (Lohmann et al. 1991; Fischmeister and Méry 1996). In transgenic mice with cardiac overexpression of eNOS or iNOS there is no cardiac abnormality except for the loss of $\beta$-adrenergic responsiveness (Massion et al. 2003; Paulus and Bronzwaer 2004; Champion et al. 2003; Ziolo et al. 2001). As seen with $\beta$-blockers, such a mechanism may prove to be protective in heart failure, and could account for the anti-hypertrophic effect of chronic cGMP pathway stimulation by NO (Kempf and Wollert 2004) or NPs (Tokudome et al. 2004).

During the last decade, we have studied cyclic nucleotide signalling in healthy and diseased adult cardiac myocytes. With a physiologist approach, we favoured functional rather than biochemical approaches. This is why we generally chose to work on intact, differentiated cardiac myocytes, isolated from small adult animals (frog, rat, mice) or from human atrial appendage. On these myocytes, we apply the patch clamp technique to record ionic currents, and in particular $\mathrm{I}_{\mathrm{Ca}, \mathrm{L}}$ which serves as a marker of cAMP and cGMP changes, as well as 
associated PKA and PKG activities in response to diverse stimuli. We developed original methods to study the spatio-temporal organisation (compartmentation) of cyclic nucleotide signalling pathways, and showed that cyclic nucleotide PDEs play a key role in defining this compartmentation.

\section{cAMP and $\beta$-adrenergic regulation of cardiac function}

Two types of $\beta$-AR ( $\beta_{1}-\mathrm{AR}$ and $\left.\beta_{2}-\mathrm{AR}\right)$ participate in the sympathetic stimulation of cardiac function (Xiao et al. 2004). We showed that both $\beta_{1}$-AR (Hartzell et al. 1991; Hartzell and Fischmeister 1992) and $\beta_{2}$-AR (Skeberdis et al. 1997a; 1997b) activated $\mathrm{I}_{\mathrm{Ca}, \mathrm{L}}$ through cAMP elevation and PKA phosphorylation. We currently study $I_{C a, L}$ regulation by $\beta_{3}-A R$, which are expressed in the human heart (Moniotte et al. 2001), and have a negative inotropic effect in the ventricle (Gauthier et al. 1996) involving activation of eNOS (Gauthier et al. 1998). We found that $\beta_{3}-\mathrm{AR}$ activate $\mathrm{I}_{\mathrm{Ca}, \mathrm{L}}$ in human atrial tissue (Skeberdis et al. 1999; Gendviliene et al. 2002), indicating tissue specificity in the downstream signalling of this receptor. Other types of receptors also activate $\mathrm{I}_{\mathrm{Ca}, \mathrm{L}}$ through an elevation in cAMP, for instance 5-HT 4 (Blondel et al. 1997; Vandecasteele et al. 1998) and glucagon (Méry et al. 1990) receptors.

\section{Opposite effects of cAMP and cGMP on cardiac ionic channels}

In 1986, we showed for the first time that intracellular cGMP counteracted the effects of cAMP on $\mathrm{I}_{\mathrm{Ca}, \mathrm{L}}$, and suggested that cGMP action involved PDE2 (Hartzell and Fischmeister 1986). This early hypothesis was confirmed much later, ought to the characterisation of EHNA as a selective PDE2 inhibitor (Méry et al. 1995). However, differences exist among species. In guinea pig (Levi et al. 1989) and rat (Méry et al. 1991), PKG accounts for the inhibitory effect of cGMP on $\mathrm{I}_{\mathrm{Ca}, \mathrm{L}}$, while PDE2 dominates in frog. In human, low concentrations of cGMP stimulate $\mathrm{I}_{\mathrm{Ca}, \mathrm{L}}$ through PDE3 inhibition, and high concentrations 
inhibit this current by stimulation of PDE2 (Vandecasteele et al. 2001). This versatility of cGMP actions on cardiac function was largely confirmed in subsequent studies, in particular in those using $\mathrm{KO}$ or transgenic mice for genes of the cGMP pathway (Wegener et al. 2002). $\mathrm{I}_{\mathrm{Ca}, \mathrm{L}}$ inhibition by cGMP participates to the anti-hypertrophic action of cGMP (Fiedler et al. 2002). However, in one animal species (rabbit), the results clearly differ. Indeed, PKG exerts stimulatory effects on rabbit cardiac $\mathrm{I}_{\mathrm{Ca}, \mathrm{L}}$, both in atrial (Wang et al. 2000) and ventricular myocytes (Han et al. 1993; 1998; Kumar et al. 1997), although the latter may be restricted to the newborn stage (Kumar et al. 1997; 1999).

\section{Does cGMP mediate the effects of NO in cardiac myocytes?}

In 1993, we showed for the first time that $\beta$-AR stimulation of $\mathrm{I}_{\mathrm{Ca}, \mathrm{L}}$ is antagonized by a NOdonor (Méry et al. 1993). We established that this effect is mediated by an elevation of cGMP (Abi-Gerges et al. 1997), which stimulates PDE2 in frog (Méry et al. 1995; Dittrich et al. 2001) and PKG in rat (Abi-Gerges et al. 2001). Surprisingly, while PKG stimulation by cGMP can inhibit $\mathrm{I}_{\mathrm{Ca}, \mathrm{L}}$ directly by phosphorylation of the channel main subunit (Méry et al. 1991; Jiang et al. 2000), PKG activation triggered by NO is mediated by a pertussis-sensitive Gi proteins, thus inhibiting adenylyl cyclase activity (Abi-Gerges et al. 2001). The functional consequence of the inhibitory effect of cGMP on $\mathrm{I}_{\mathrm{Ca}, \mathrm{L}}$ is the negative inotropic effect of NO (Chesnais et al. 1999a). In human atrial tissue, NO, like cGMP (Vandecasteele et al. 2001), exerts a dual action on $\mathrm{I}_{\mathrm{Ca}, \mathrm{L}}$, due to the opposite action of cGMP on PDE2 and PDE3 (Kirstein et al. 1995). But NO has also cGMP-independent effects (Fischmeister and Méry 1996). For instance we found that very low doses of NO activate Gs, stimulating adenylyl cyclase and $\mathrm{I}_{\mathrm{Ca}, \mathrm{L}}$, and $\mathrm{Gi}$, hence stimulating the muscarinic $\mathrm{K}^{+}$channels (Abi-Gerges et al. 2002). NO may also bind superoxide anions to form peroxynitrite, which exerts specific effects on cardiac 
$\mathrm{I}_{\mathrm{Ca}, \mathrm{L}}$ (Campbell et al. 1996; Malan et al. 2003) and contraction (Ronson et al. 1999; Chesnais et al. 1999b).

\section{NO and cGMP effects on other cardiac channels}

Although much effort has been devoted to examine the effect of NO and cGMP on cardiac

$\mathrm{Ca}^{2+}$ channels, other cardiac ion channels have also been shown to be regulated by this pathway. For instance, in rabbit ventricular myocytes, the ATP-sensitive $\mathrm{K}^{+}$channel current $\mathrm{I}_{\mathrm{K}(\mathrm{ATP})}$ is activated by NO donors, and this involves both activation of PKG (Han et al. 2002) and cGMP-independent effects (Sasaki et al. 2000). The hyperpolarization-activated pacemaker current $\mathrm{I}_{\mathrm{f}}$ is also activated by NO and cGMP in guinea pig sinoatrial myocytes due to cGMP-inhibition of PDE3, but this effect is transient due to a subsequent cGMP-activation of PDE2 (Herring et al. 2001). In human atrial myocytes, $I_{f}$ is enhanced by the atrial natriuretic peptide ANP, and this effect likely involves cGMP-inhibition of PDE3 (Lonardo et al. 2004). Finally, Ahmmed et al. (2001) found that NO reduces the voltage-dependent fast $\mathrm{Na}^{+}$current in guinea pig and mouse ventricular myocytes, through a mechanism involving activation of both PKG and PKA.

\section{Does cGMP mediates the effects of acetylcholine in cardiac myocytes?}

In the early 70's, the observation that cGMP increases upon parasympathetic stimulation, together with its negative inotropic properties led many scientists to hypothesise that cGMP was responsible for the cardiac effects of ACh (Goldberg et al. 1975). However in the mid80 's, the study of the muscarinic regulation on isolated cells showed that ACh blocks $\beta$-AR stimulation of $\mathrm{I}_{\mathrm{Ca}, \mathrm{L}}$ but not a direct stimulation by cAMP (Fischmeister and Hartzell 1986; Hescheler et al. 1986), demonstrating that the effect of ACh was due exclusively to adenylyl cyclase inhibition (Harvey and Belevych 2003). The discovery of NO in the beginning of the 
90 's and of the multiple sources of NO in the heart has renewed interest for the participation of NO/cGMP in the parasympathetic regulation of the heart. This brought contradictory results however (Méry et al. 1997; Harvey and Belevych 2003; Massion et al. 2003; Herring et al. 2002). Our contribution to this debate has been to test the effects of NOS inhibitors on ACh regulation of $\mathrm{I}_{\mathrm{Ca}, \mathrm{L}}$ (Méry et al. 1996; Vandecasteele et al. 1998), and to examine muscarinic regulation of $\mathrm{I}_{\mathrm{Ca}, \mathrm{L}}$ and cardiac force in a eNOS-deficient mouse strain (Vandecasteele et al. 1999). We found that without eNOS, muscarinic regulation is not modified, in frog, mouse or man.

\section{Cyclic nucleotide phosphodiesterases}

Our interest for PDE comes from the fact that cGMP can abolish all cardiac effect of cAMP by activating its hydrolysis (Hartzell and Fischmeister 1986). Since the beginning of the 90's, more than ten PDE families are known (Rybalkin et al. 2003; Maurice et al. 2003), often with several genes in the family and several splice variants for each gene. In the cardiac myocyte, 4 PDE families have been identified (Maurice et al. 2003): PDE1 ( $\mathrm{Ca}^{2+} /$ calmodulin-activated); PDE2 (cGMP-activated); PDE3 (cGMP-inhibited); and PDE4. PDE1, 2 and 3 hydrolyse both cAMP and cGMP; PDE4 hydrolyses exclusively cAMP. PDE1 and 2 display a low affinity for both substrates, while PDE3 and 4 have a high affinity. Some evidence exists suggesting that the cGMP-specific PDE5, which is the target of sildenafil (Viagra ${ }^{\mathrm{TM}}$ ) might be also present in cardiac myocytes (Maurice et al. 2003; Reffelmann and Kloner 2003; Takimoto et al. 2005a; 2005b). Using family-specific PDE inhibitors, we showed that PDE3 and PDE4 modulate $\beta$-AR stimulation of $\mathrm{I}_{\mathrm{Ca}, \mathrm{L}}$ in frog cardiomyocytes (Fischmeister and Hartzell 1990; 1991) as well as in rats (Verde et al. 1999). In frog, PDE2 is recruited only upon cGMP elevation (Méry et al. 1995), but in human atrial cells, PDE2 regulates $\mathrm{I}_{\mathrm{Ca}, \mathrm{L}}$ even in basal conditions (Rivet-Bastide et al. 1997), as does PDE3 (Kirstein et al. 1995). Some 
heterogeneous expression or distribution of the different PDE isoforms may account for their variable contribution to cardiac function between species and tissues (Hove-Madsen et al. 1996).

\section{Subcellular compartmentation of cAMP and cGMP}

The first evidences for a compartmentation of the cAMP pathway were obtained in the 70's, in studies showing important differences between $\beta$-AR and PGE1 stimulations on cardiac cAMP level in subcellular fractions, and phosphorylation and/or activation of various PKA targets (Keely 1977; Brunton et al. 1979). But it was only recently that cyclic nucleotide compartmentation in the heart was recognised, owing to the discovery of PKA anchoring proteins (AKAP) (Michel and Scott 2002) and macro-molecular complexes (Marx et al. 2002), and to the development of fluorescent probes allowing to visualize the changes in cAMP (Adams et al. 1991; Zaccolo et al. 2000; Nikolaev et al. 2004) and cGMP (Honda et al. 2001) concentrations in intact cells.

In 1996, we developed a double-barrelled micro-perfusion technique that allowed to apply an activator of the cAMP pathway on one side of the cell, and monitor its effect on the other side (Jurevičius and Fischmeister 1996). Using the $\mathrm{Ca}^{2+}$ current as a marker of cAMP/PKA inside the cell, we demonstrated that in frog ventricular myocytes cAMP generated by a $\beta$-AR stimulation did not diffuse freely inside the cell, but remained confined on the side of the cell where it was produced. This cAMP compartmentation involves PDE activity, mainly type 3 and 4 isoforms (Jurevičius et al. 2003), since when these PDEs are inhibited, cAMP freely diffuses in the cytoplasm. A compartmentation would also participate in cGMP effects. Indeed, we showed that application of a NO-donor on one side of a cardiac cell very efficiently blocks $\beta$-AR stimulation of $\mathrm{I}_{\mathrm{Ca}, \mathrm{L}}$ on the exposed part, but has very little effect on the other part, indicating that diffusion of cGMP signals is also limited (Dittrich et al. 2001). 
In order to visualise changes in cAMP concentration, we developed two types of strategies: i) the fluorescent probe FlCRhR developed by Adams et al. (1991) was introduced inside a myocyte while measuring $\mathrm{I}_{\mathrm{Ca}, \mathrm{L}}$ simultaneously (Goaillard et al. 2001); and ii) a channel that is directly opened by cAMP beneath the membrane (Rich et al. 2000) was expressed in cardiac myocytes by adenoviral transfer. This channel is formed by the $\alpha$ subunit of the rat olfactory (CNGA2), that belongs to the CNG channel family (ㄷyclic Nucleotide Gated Channels. Since the wild type CNGA2 has a higher affinity for cGMP than for cAMP, we used mutant forms, more sensitive to cAMP. With this approach we showed that cAMP generated by $\beta$-AR is compartmented in rat ventricular myocytes, due to strong PDE3 and PDE4 activities (Rochais et al. 2004). The role of PDE4 in this compartmentation was just confirmed by an independent study (Mongillo et al. 2004). We show in addition that PDE activation is under the control of PKA since PKA inhibition reveals global cAMP signals upon $\beta$-AR stimulation (Rochais et al. 2004).

\section{cAMP pathway in hypertrophy and heart failure}

The molecular components of the cAMP pathway are critically modified in all forms of heart failure (Port and Bristow 2001; Lohse et al. 2003; Movsesian 2004). Increased levels of catecholamines in hypertrophy and heart failure lead to a loss of $\beta$-AR is observed, principally of $\beta 1-\mathrm{AR}$, an increased expression of $\beta \mathrm{ARK}$ responsible for $\beta$-AR desensitisation, an increase in $\mathrm{G}_{\mathrm{i}}$ proteins (El-Armouche et al. 2003), a decreased adenylyl cyclase activity, and a globally decreased cAMP level. One of the consequence is a diminished phosphorylation of PKA targets, in particular phospholamban (PLB), phosphatase 1 inhibitor (I-1) (El-Armouche et al. 2004) and contractile proteins (Van der Velden et al. 2003), leading to a diminished efficiency in $\mathrm{Ca}^{2+}$ cycling (Hasenfuss and Pieske 2002) and to the collapse of the contractile response to a $\beta$-AR stimulation. Other alterations concern cAMP control of gene expression, 
with a desensitisation of CRE (cAMP Responsive Element) transcriptional activity (Muller et al. 2001). In contrast, the ryanodine receptor (RyR2) is hyperphosphorylated by PKA in heart failure (Marx et al. 2000), indicating a profound perturbation of cAMP targeting in the diseased cell.

In a similar manner, chronic exposure to $\beta_{1}$-AR agonists in cellular or animal models, the cardiac overexpression of $\beta_{1}$-AR (Engelhardt et al. 1999), Gs proteins (Iwase et al. 1996), or PKA (Antos et al. 2001), all lead to hypertrophy, apoptosis, and heart failure, through intracellular $\mathrm{Ca}^{2+}$ elevation and activation of calcineurin/NFAT (Saito et al. 2002). But, while chronic activation of the cAMP pathway participates to its own collapse, any elevation of cAMP does not automatically cause deleterious effects. For instance, transgenic mice overexpressing $\beta 2-\mathrm{AR}$ in the heart (Milano et al. 1994), AC6 (Roth et al. 1999) or AC8 (Lipskaia et al. 2000; Georget et al. 2002; 2003) do not show early signs of hypertrophy or heart failure. As stated by a recent editorial (Bers and Ziolo 2001) "When is cAMP not cAMP?" We believe that cAMP compartmentation is a key actor and determines the quality of the response.

\section{NO/cGMP pathway in hypertrophy and heart failure}

In hypertrophy and heart failure, the heart produces and secretes important quantities of ANP, BNP and CNP (Abassi et al. 2004), and BNP is being used as a diagnosis marker of heart failure (Tabbibizar and Maisel 2002). NO production is also increases in the failing heart, in part due to iNOS (Massion et al. 2003; Paulus and Bronzwaer 2004) and nNOS expression (Damy et al. 2004). A large body of evidence indicates that NP (Tokudome et al. 2004; Rosenkranz et al. 2003) and NO (Kempf and Wollert 2004) exert a direct anti-hypertrophic effect in cardiac myocytes. Increased NP and NO production is likely to represent a protective mechanism, independently of their peripheral actions. These effects of NP and NO are 
mediated by cGMP, which would inhibit the calcineurin/NFAT pathway via a PKG-mediated inhibition of $\mathrm{I}_{\mathrm{Ca}, \mathrm{L}}$ (Méry et al. 1991; Fiedler et al. 2002). But PKG could also act at the transcriptional level independently of NFAT, on other transcription factors such as SRF, ATF-1, CREB, etc. (Pilz and Casteel 2003), as well as on mitochondrial biogenesis (Nisoli et al. 2003).

\section{Conclusion}

In 1975, Goldberg and colleagues introduced the Yin-Yang hypothesis based on their observations that cAMP and cGMP exerted opposite actions on cardiac function. Thirty years later, our understanding of how these two cyclic nucleotides mediate their cardiac actions has greatly progressed, but the Yin-Yang hypothesis remains essentially valid. Today, we know that the NO/cGMP pathway not only antagonizes the cAMP pathway under acute conditions, but most importantly also in the chronic setting, with cAMP activating and cGMP inhibiting the hypertrophic program. Both cyclic nucleotides appear to be compartmentalized and it is likely that their relative concentrations in different subcellular compartments will determine the overall response of the heart to hormones, neurotransmitters and NO. Since cAMP signalling is altered in hypertrophy and heart failure, it is likely that cGMP signalling will be too. A major challenge will be to understand the remodelling of cAMP/cGMP signalling and its subcellular compartmentation during hypertrophy, and how this contributes to the development of heart failure. 


\section{REFERENCES}

Abassi, Z., Karram, T. , Ellaham, S., Winaver, J., Hoffman, A., 2004. Implications of the natriuretic peptide system in the pathogenesis of heart failure: diagnostic and therapeutic importance. Pharmacol. Ther. 102, 223-241.

Abi-Gerges, N., Fischmeister, R., Méry, P.-F., 2001. G protein-mediated inhibitory effect of a nitric oxide donor on the L-type $\mathrm{Ca}^{2+}$ current in rat ventricular myocytes. J. Physiol. 531, 117130.

Abi-Gerges, N., Hove-Madsen, L., Fischmeister, R., Méry, P.-F., 1997. A comparative study of the effects of three guanylyl cyclase inhibitors on the L-type $\mathrm{Ca}^{2+}$ and muscarinic $\mathrm{K}^{+}$ currents in frog cardiac myocytes. Br. J. Pharmacol. 121, 1369-1377.

Abi-Gerges, N., Ji, G. J., Lu, Z. J., Fischmeister, R., Hescheler, J., Fleischmann, B. K., 2000. Functional expression and regulation of the hyperpolarization activated non-selective cation current in embryonic stem cell-derived cardiomyocytes. J. Physiol. 523, 377-389.

Abi-Gerges, N., Szabo, G., Otero, A. S., Fischmeister, R., Méry, P.-F., 2002. NO donors potentiate the $\beta$-adrenergic stimulation of $I_{C a, L}$ and the muscarinic activation of $I_{K, A C h}$ in rat cardiac myocytes. J. Physiol. 540, 411-424.

Abi-Gerges, N., Tavernier, B., Mebazaa, A., Faivre, V., Paqueron, X., Payen, D., Fischmeister, R., Méry, P.-F., 1999. Sequential changes in autonomic regulation of cardiac myocytes after in vivo endotoxin injection in rat. Am. J. Resp. Critical Care Med. 160, 11961204.

Adams, S. R., Harootunian, A. T., Buechler, Y. J., Taylor, S. S., Tsien, R. Y., 1991.

Fluorescence ratio imaging of cyclic AMP in single cells. Nature 349, 694-697. 
Ahmmed, G. U., Xu, Y., Hong Dong, P., Zhang, Z., Eiserich, J., Chiamvimonvat, N., 2001.

Nitric oxide modulates cardiac $\mathrm{Na}^{+}$channel via protein kinase A and protein kinase G. Circ. Res. 89, 1005-1013.

Antos, C. L., Frey, N., Marx, S. O., Reiken, S., Gaburjakova, M., Richardson, J. A., Marks, A. R., Olson, E. N., 2001. Dilated cardiomyopathy and sudden death resulting from constitutive activation of protein kinase A. Circ. Res. 89, 997-1004.

Bers, D. M., Ziolo, M. T., 2001. When is cAMP not cAMP? Effects of compartmentalization. Circ. Res. 89, 373-375.

Bers, D. M., 2002. Cardiac excitation-contraction coupling. Nature 415, 198-205.

Blondel, O., Vandecasteele, G., Gastineau, M., Leclerc, S., Dahmoune, Y., Langlois, M., Fischmeister, R., 1997. Molecular and functional characterization of a 5-HT 4 receptor cloned from human atrium. FEBS Lett. 412, 465-474.

Brunton, L. L., Hayes, J. S., Mayer, S. E., 1979. Hormonally specific phosphorylation of cardiac troponin I and activation of glycogen phosphorylase. Nature 280, 78-80.

Campbell, D. L., Stamler, J. S., Strauss, H. C., 1996. Redox modulation of L-type calcium channels in ferret ventricular myocytes - Dual mechanism regulation by nitric oxide and Snitrosothiols. J. Gen. Physiol. 108, 277-293.

Champion, H. C., Georgakopoulos, D., Takimoto, E., Isoda, T., Wang, Y., Kass, D. A., 2004. Modulation of in vivo cardiac function by myocyte-specific nitric oxide synthase-3. Circ. Res. 94, 657-63.

Chesnais, J. M., Fischmeister, R., Méry, P.-F., 1999a. Positive and negative inotropic effects of NO donors in atrial and ventricular fibres of the frog heart. J. Physiol. 518, 449-461. 
Chesnais, J. M., Fischmeister, R., Méry, P.-F., 1999b. Peroxynitrite is a positive inotropic agent in atrial and ventricular fibres of the frog heart. J. Physiol. 521, 375-388.

Damy, T., Ratajczak, P., Shah, A. M., Camors, E., Marty, I., Hasenfuss, G., Marotte, F., Samuel, J. L., Heymes, C., 2004. Increased neuronal nitric oxide synthase-derived NO production in the failing human heart. Lancet 363, 1365-1367.

Dittrich, M., Jurevičius, J., Georget, M., Rochais, F., Fleischmann, B. K., Hescheler, J., Fischmeister, R., 2001. Local response of L-type $\mathrm{Ca}^{2+}$ current to nitric oxide in frog ventricular myocytes. J. Physiol. 534, 109-121.

El-Armouche, A., Pamminger, T., Ditz, D., Zolk, O., Eschenhagen, T., 2004. Decreased protein and phosphorylation level of the protein phosphatase inhibitor-1 in failing human hearts. Cardiovasc. Res. 61, 87-93.

El-Armouche, A., Zolk, O., Rau, T., Eschenhagen, T., 2003. Inhibitory G-proteins and their role in desensitization of the adenylyl cyclase pathway in heart failure. Cardiovasc. Res. 60, 478-487.

Engelhardt, S., Hein, L., Wiesmann, F., Lohse, M. J., 1999. Progressive hypertrophy and heart failure in beta1-adrenergic receptor transgenic mice. Proc. Natl Acad. Sci. USA 96, 7059-7064.

Fiedler, B., Lohmann, S. M., Smolenski, A., Linnemuller, S., Pieske, B., Schroder, F., Molkentin, J. D., Drexler, H., Wollert, K. C., 2002. Inhibition of calcineurin-NFAT hypertrophy signaling by cGMP-dependent protein kinase type I in cardiac myocytes. Proc. Natl Acad. Sci. USA 99, 11363-11368. 
Fischmeister, R., Hartzell, H. C., 1986. Mechanism of action of acetylcholine on calcium current in single cells from frog ventricle. J. Physiol. 376, 183-202.

Fischmeister, R., Hartzell, H. C., 1990. Regulation of calcium current by low-K $\mathrm{m}_{\mathrm{m}}$ cyclic AMP phosphodiesterases in cardiac cells. Mol. Pharmacol. 38, 426-433.

Fischmeister, R., Hartzell, H. C., 1991. Cyclic AMP phosphodiesterases and $\mathrm{Ca}^{2+}$ current regulation in cardiac cells. Life Sci. 48, 2365-2376.

Fischmeister, R., Méry, P.-F., 1996. Régulation du courant calcique cardiaque par la voie du GMPc/NO. CR Séances Soc. Biol. 190, 181-206.

Gauthier, C., Leblais, V., Kobzik, L., Trochu, J. N., Khandoudi, N., Bril, A., Balligand, J. L., LeMarec, H., 1998. The negative inotropic effect of $\beta_{3}$-adrenoreceptor stimulation is mediated by activation of a nitric oxide synthase pathway in human ventricle. J. Clin. Invest. 102, 13771384.

Gauthier, C., Tavernier, G., Charpentier, F., Langin, D., Lemarec, H., 1996. Functional $\beta_{3}{ }^{-}$ adrenoceptor in the human heart. J. Clin. Invest. 98, 556-562.

Gendviliene, V., Macianskiene, R., Skeberdis, A., Kanaporis, G., Zablockaite, D., Jurevičius, J., Fischmeister, R., 2002. Effect of nonconventional beta-adrenoceptor agonist CGP 12177 on L-type calcium current and contraction force in human myocardium. Biomedicine 2, 4650.

Georget, M., Mateo, P. , Vandecasteele, G., Jurevičius, J., Lipskaia, L., Defer, N., Hanoune, J., Hoerter, J., Fischmeister, R., 2002. Augmentation of cardiac contractility with no change in L-type $\mathrm{Ca}^{2+}$ current in transgenic mice with a cardiac-directed expression of the human adenylyl cyclase type 8 (AC8). FASEB J. 16, 1636-1638. 
Georget, M., Mateo, P. , Vandecasteele, G., Lipskaia, L., Defer, N., Hanoune, J., Hoerter, J., Lugnier, C., Fischmeister, R., 2003. Cyclic AMP compartmentation due to increased cAMPphosphodiesterase activity in transgenic mice with a cardiac-directed expression of the human adenylyl cyclase type 8 (AC8). FASEB J. 17, 1380-1391.

Goaillard, J. M., Vincent, P. V., Fischmeister, R., 2001. Simultaneous measurements of intracellular cAMP and L-type $\mathrm{Ca}^{2+}$ current in single frog ventricular myocytes. J. Physiol. 530, 79-91.

Goldberg, N. D., Haddox, M. K., Nicol, S. E., Glass, D. B., Sanford, C. H., Kuehl, F. A. J., Estensen, R., 1975. Biologic regulation through opposing influences of cyclic GMP and cyclic AMP: the Yin Yang hypothesis. Adv. Cyclic Nucl. Res. 5, 307-330.

Han, J., Kim, N., Joo, H., Kim, E., Earm, Y. E., 2002. ATP-sensitive $\mathrm{K}^{+}$channel activation by nitric oxide and protein kinase $\mathrm{G}$ in rabbit ventricular myocytes. Am. J. Physiol. Heart Circul. Physiol. 283, H1545-H1554.

Han, J., Kim, E., Lee, S. H., Yoo, S., Ho, W. K., Earm, Y. E., 1998. cGMP facilitates calcium current via cGMP-dependent protein kinase in isolated rabbit ventricular myocytes. Pflügers Arch. 435, 388-393.

Han, J., Leem, C., Ahn, C., So, I., Kim, E., Ho, W., Earm, Y. E., 1993. Effect of cyclic GMP on the calcium current in rabbit ventricular myocytes. Kor. J. Physiol. 27, 151-162.

Hartzell, H. C., Fischmeister, R., 1986. Opposite effects of cyclic GMP and cyclic AMP on $\mathrm{Ca}^{2+}$ current in single heart cells. Nature 323, 273-275.

Hartzell, H. C., Fischmeister, R., 1992. Direct regulation of cardiac $\mathrm{Ca}^{2+}$ channels by Gproteins - Neither proven nor necessary? Trends Pharmacol. Scie. 13, 380-385. 
Hartzell, H. C., Méry, P.-F., Fischmeister, R., Szabo, G., 1991. Sympathetic regulation of cardiac calcium current is due exclusively to cAMP-dependent phosphorylation. Nature 351, $573-576$.

Harvey, R. D., Belevych, A. E., 2003. Muscarinic regulation of cardiac ion channels. Br. J. Pharmacol. 139, 1074-1084.

Hasenfuss, G., Pieske, B., 2002. Calcium cycling in congestive heart failure. J. Mol. Cell. Cardiol. 34, 951-969.

Herring, N., Danson, E. J. F., Paterson, D. J., 2002. Cholinergic control of heart rate by nitric oxide is site specific. News Physiol. Sci. 17, 202-206.

Herring, N., Rigg, L., Terrar, D. A., Paterson, D. J., 2001. NO-cGMP pathway increases the hyperpolarisation-activated current, $\mathrm{I}_{\mathrm{f}}$, and heart rate during adrenergic stimulation. Cardiovasc. Res. 52, 446-453.

Hescheler, J., Kameyama, M., Trautwein, W., 1986. On the mechanism of muscarinic inhibition of the cardiac Ca current. Pflügers Archiv. 407, 182-189.

Honda, A., Adams, S. R., Sawyer, C. L., Lev-Ram, V., Tsien, R. Y., Dostmann, W. R., 2001. Spatiotemporal dynamics of guanosine 3',5'-cyclic monophosphate revealed by a genetically encoded, fluorescent indicator. Proc. Natl Acad. Sci. USA 98, 2437-2442.

Hove-Madsen, L., Méry, P.-F., Jurevičius, J., Skeberdis, A. V., Fischmeister, R., 1996. Regulation of myocardial calcium channels by cyclic AMP metabolism. Bas. Res. Cardiol. 91 (Suppl. 2), 1-8.

Iwase, M., Bishop, S. P., Uechi, M., Vatner, D. E., Shannon, R. P., Kudej, R. K., Wight, D. C., Wagner, T. E., Ishikawa, Y., Homcy, C. J., Vatner, S. F., 1996. Adverse effects of chronic 
endogenous sympathetic drive induced by cardiac $\mathrm{G}_{\mathrm{s}}$ alpha overexpression. Circ. Res. 78, 517-524.

Jiang, L. H., Gawler, D. J., Hodson, N., Milligan, C. J., Pearson, H. A., Porter, V., Wray, D., 2000. Regulation of cloned cardiac L-type calcium channels by cGMP-dependent protein kinase. J. Biol. Chem. 275, 6135-6143.

Jurevičius, J., Fischmeister, R., 1996. cAMP compartmentation is responsible for a local activation of cardiac $\mathrm{Ca}^{2+}$ channels by $\beta$-adrenergic agonists. Proc. Natl Acad. Sci. USA 93, 295-299.

Jurevičius, J., Skeberdis, V. A., Fischmeister, R., 2003. Role of cyclic nucleotide phosphodiesterase isoforms in cAMP compartmentation following $\beta_{2}$ - adrenergic stimulation of $\mathrm{I}_{\mathrm{Ca}, \mathrm{L}}$ in frog ventricular myocytes. J. Physiol. 551, 239-252.

Keely, S. L., 1977. Activation of cAMP-dependent protein kinase without a corresponding increase in phosphorylase activity. Res. Comm. Chem. Pathol. Pharmacol. 18, 283-290.

Kempf, T., Wollert, K. C., 2004. Nitric oxide and the enigma of cardiac hypertrophy. Bioessays 26, 608-615.

Kirstein, M., Rivet-Bastide, M., Hatem, S., Bénardeau, A., Mercadier, J. J., Fischmeister, R., 1995. Nitric oxide regulates the calcium current in isolated human atrial myocytes. J. Clin. Invest. 95, 794-802.

Kumar, R., Joyner, R. W., Komalavilas, P., Lincoln, T. M., 1999. Analysis of expression of cGMP-dependent protein kinase in rabbit heart cells. J. Pharmacol. Exp. Ther. 291, 967-975.

Kumar, R., Namiki, T., Joyner, R. W., 1997. Effects of cGMP on L-type calcium current of adult and newborn rabbit ventricular cells. Cardiovasc. Res. 33, 573-582. 
Levi, R. C., Alloatti, G., Fischmeister, R., 1989. Cyclic GMP regulates the Ca-channel current in guinea pig ventricular myocytes. Pflügers Archiv. 413, 685-687.

Lipskaia, L., Defer, N., Esposito, G., Hajar, I., Garel, M. C., Rockman, H. A., Hanoune, J., 2000. Enhanced cardiac function in transgenic mice expressing a $\mathrm{Ca}^{2+}$-stimulated adenylyl cyclase. Circ. Res. 86, 795-801.

Lohmann, S. M., Fischmeister, R., Walter, R., 1991. Signal transduction by cGMP in heart. Bas. Res. Cardiol. 86, 503-514.

Lohse, M. J., Engelhardt, S., Eschenhagen, T., 2003. What is the role of beta-adrenergic signaling in heart failure? Circ. Res. 93, 896-906.

Lonardo, G., Cerbai, E., Casini, S., Giunti, G., Bonacchi, M., Battaglia, F., Fiorani, B., Stefano, P. L., Sani, G., Mugelli, A., 2004. Atrial natriuretic peptide modulates the hyperpolarization-activated current $\left(\mathrm{I}_{\mathrm{f}}\right)$ in human atrial myocytes. Cardiovasc. Res. 63, 528536.

Malan, D., Levi, R. C., Alloatti, G., Marcantoni, A., Bedendi, I., Gallo, M. P., 2003. Cyclic AMP and cyclic GMP independent stimulation of ventricular calcium current by peroxynitrite donors in guinea pig myocytes. J. Cell. Physiol. 197, 284-296.

Marx, S. O., Kurokawa, J., Reiken, S., Motoike, H., D'Armiento, J., Marks, A. R., Kass, R. S., 2002. Requirement of a macromolecular signaling complex for $\beta$ adrenergic receptor modulation of the KCNQ1-KCNE1 potassium channel. Science 295, 496-499.

Marx, S. O., Reiken, S., Hisamatsu, Y., Jayaraman, T., Burkhoff, D., Rosemblit, N., Marks, A. R., 2000. PKA phosphorylation dissociates FKBP12.6 from the calcium release channel (Ryanodine receptor): Defective regulation in failing hearts. Cell 101, 365-376. 
Massion, P. B., Feron, O., Dessy, C., Balligand, J. L., 2003. Nitric oxide and cardiac function - Ten years after, and continuing. Circ. Res. 93, 388-398.

Maurice, D. H., Palmer, D., Tilley, D. G., Dunkerley, H. A., Netherton, S. J., Raymond, D.

R., Elbatarny, H. S., Jimmo, S. L., 2003. Cyclic nucleotide phosphodiesterase activity, expression, and targeting in cells of the cardiovascular system. Mol. Pharmacol. 64, 533-546.

Méry, P.-F., Abi-Gerges, N., Vandecasteele, G., Jurevičius, J., Eschenhagen, T., Fischmeister, R., 1997. Muscarinic regulation of the L-type calcium current in isolated cardiac myocytes. Life Sci. 60, 1113-1120.

Méry, P.-F., Brechler, V., Pavoine, C., Pecker, F., Fischmeister, R., 1990. Glucagon stimulates the cardiac $\mathrm{Ca}^{2+}$ current by activation of adenylyl cyclase and inhibition of phosphodiesterase. Nature 345, 158-161.

Méry, P.-F., Hove-Madsen, L., Chesnais, J. M., Hartzell, H. C., Fischmeister, R., 1996. Nitric oxide synthase does not participate in negative inotropic effect of acetylcholine in frog heart. Am. J. Physiol. Heart Circ. Physiol. 39, H1178-H1188.

Méry, P.-F., Pavoine, C., Belhassen, L., Pecker, F., Fischmeister, R., 1993. Nitric oxide regulates cardiac $\mathrm{Ca}^{2+}$ current - Involvement of cGMP-inhibited and cGMP-stimulated phosphodiesterases through guanylyl cyclase activation. J. Biol. Chem. 268, 26286-26295.

Méry, P.-F., Pavoine, C., Pecker, F., Fischmeister, R., 1995. Erythro-9-(2-hydroxy-3nonyl)adenine inhibits cyclic GMP-stimulated phosphodiesterase in isolated cardiac myocytes. Mol. Pharmacol. 48, 121-130. 
Méry, P.-F., Lohmann, S. M., Walter, U., Fischmeister, R., 1991. $\mathrm{Ca}^{2+}$ current is regulated by cyclic GMP-dependent protein kinase in mammalian cardiac myocytes. Proc. Natl Acad. Sci. USA 88, 1197-1201.

Michel, J. J. C., Scott, J. D., 2002. AKAP mediated signal transduction. Ann. Rev. Pharmacol. Toxicol. 42, 235-257.

Milano, C. A., Allen, L. F., Rockman, H. A., Dolber, P. C., Mcminn, T. R., Chien, K. R., Johnson, T. D., Bond, R. A., Lefkowitz, R. J., 1994. Enhanced myocardial function in transgenic mice overexpressing the $\beta_{2}$-adrenergic receptor. Science $264,582-586$.

Mongillo, M., McSorley, T., Evellin, S., Sood, A., Lissandron, V., Terrin, A., Huston, E., Hannawacker, A., Lohse, M. J., Pozzan, T., Houslay, M. D., Zaccolo, M., 2004. Fluorescence resonance energy transfer-based analysis of cAMP dynamics in live neonatal rat cardiac myocytes reveals distinct functions of compartmentalized phosphodiesterases. Circ. Res. 95, $65-75$.

Moniotte, S., Vaerman, J., Kockx, M. M., Larrouy, D., Langin, D., Noirhomme, P., Balligand, J., 2001. Real-time RT-PCR for the detection of beta-adrenoceptor messenger RNAs in small human endomyocardial biopsies. J. Mol. Cell. Cardiol. 33, 2121-2133.

Movsesian, M. A., 2004. Altered cAMP-mediated signalling and its role in the pathogenesis of dilated cardiomyopathy. Cardiovasc. Res. 62, 450-459.

Muller, F. U., Boknik, P., Knapp, J., Linck, B., Luss, H., Neumann, J., Schmitz, W., 2001. Activation and inactivation of cAMP-response element-mediated gene transcription in cardiac myocytes. Cardiovasc. Res. 52, 95-102. 
Nikolaev, V. O., Bunemann, M., Hein, L., Hannawacker, A., Lohse, M. J., 2004. Novel single chain cAMP sensors for receptor-induced signal propagation. J. Biol. Chem. 279, 3721537218.

Nisoli, E., Clementi, E., Paolucci, C., Cozzi, V., Tonello, C., Sciorati, C., Bracale, R., Valerio, A., Francolini, M., Moncada, S., Carruba, M. O., 2003. Mitochondrial biogenesis in mammals: the role of endogenous nitric oxide. Science 299, 896-869.

Paulus, W. J., Bronzwaer, J. G., 2004. Nitric oxide's role in the heart: control of beating or breathing? Am. J. Physiol. Heart Circ. Physiol 287, H8-H13.

Pilz, R. B., Casteel, D. E., 2003. Regulation of gene expression by cyclic GMP. Circ. Res. 93, 1034-1046.

Port, J. D., Bristow, M. R., 2001. $\beta$-adrenergic receptors, transgenic mice, and pharmacological model systems. Mol. Pharmacol. 60, 629-631.

Rapundalo, S. T., 1998. Cardiac protein phosphorylation: functional and pathophysiological correlates. Cardiovasc. Res. 38, 559-588.

Reffelmann, T., Kloner, R. A., 2003. Therapeutic potential of phosphodiesterase 5 inhibition for cardiovascular disease. Circulation 108, 239-244.

Rich, T. C., Fagan, K. A., Nakata, H., Schaack, J., Cooper, D. M. F., Karpen, J. W., 2000. Cyclic nucleotide-gated channels colocalize with adenylyl cyclase in regions of restricted cAMP diffusion. J. Gen. Physiol. 116, 147-161.

Rivet-Bastide, M., Vandecasteele, G., Hatem, S., Verde, I., Benardeau, A., Mercadier, J. J., Fischmeister, R., 1997. cGMP-stimulated cyclic nucleotide phosphodiesterase regulates the basal calcium current in human atrial myocytes. J. Clin. Invest. 99, 2710-2718. 
Robinson, R. B., Siegelbaum, S. A., 2003. Hyperpolarization-activated cation currents: From Molecules to Physiological Function. Ann. Rev. Physiol. 65, 453-480.

Rochais, F., Vandecasteele, G., Lefebvre, F., Lugnier, C., Lum, H., Mazet, J.-L., Cooper, D. M. F., Fischmeister, R., 2004. Negative feedback exerted by PKA and cAMP phosphodiesterase on subsarcolemmal cAMP signals in intact cardiac myocytes. An in vivo study using adenovirus-mediated expression of CNG channels. J. Biol. Chem. 279, 5209552105.

Ronson, R. S., Nakamura, M., Vinten-Johansen, J., 1999. The cardiovascular effects and implications of peroxynitrite. Cardiovasc. Res. 44, 47-59.

Rosenkranz, A. C., Woods, R. L., Dusting, G. J., Ritchie, R. H., 2003. Antihypertrophic actions of the natriuretic peptides in adult rat cardiomyocytes: importance of cyclic GMP. Cardiovasc. Res. 57, 515-522.

Roth, D. M., Gao, M. H., Lai, N. C., Drumm, J., Dalton, N., Zhou, J. Y., Zhu, J., Entrikin, D., Hammond, K., 1999. Cardiac-directed adenylyl cyclase expression improves heart function in murine cardiomyopathy. Circulation 99, 3099-3102.

Rybalkin, S. D., Yan, C., Bornfeldt, K. E., Beavo, J. A., 2003. Cyclic GMP phosphodiesterases and regulation of smooth muscle function. Circ. Res. 93, 280-291. Saito, S., Hiroi, Y., Zou, Y., Aikawa, R., Toko, H., Shibasaki, F., Yazaki, Y., Nagai, R., Komuro, I., 2000. $\beta$-adrenergic pathway induces apoptosis through calcineurin activation in cardiac myocytes. J. Biol. Chem. 275, 34528-34533. 
Sartiani, L., Bochet, P., Cerbai, E., Mugelli, A., Fischmeister, R., 2002. Functional expression of the hyperpolarization-activated, non-selective cation current $\mathrm{I}_{\mathrm{f}}$ in immortalized HL-1 cardiomyocytes. J. Physiol. 545, 81-92.

Sasaki, N., Sato, T., Ohler, A., O'Rourke, B., Marban, E., 2000. Activation of mitochondrial ATP-dependent potassium channels by nitric oxide. Circulation 101, 439-445.

Skeberdis, V. A., Jurevičius, J., Fischmeister, R., 1997a. Pharmacological characterization of the receptors involved in the $B$-adrenoceptor-mediated stimulation of the L-type $\mathrm{Ca}^{2+}$ current in frog ventricular myocytes. Br. J. Pharmacol. 121, 1277-1286.

Skeberdis, V. A., Jurevičius, J., Fischmeister, R., 1997b. $2_{2}$ adrenergic activation of L-type $\mathrm{Ca}^{++}$current in cardiac myocytes. J. Pharmacol. Exp. Ther. 283, 452-461.

Skeberdis, V. A., Jurevičius, J., Fischmeister, R., 1999. $\beta_{3}$-adrenergic regulation of the L-type $\mathrm{Ca}^{2+}$ current in human atrial myocytes. Biophys. J. 76, A343.

Swynghedauw, B., 2004. L'insuffisance cardiaque chronique de l'adulte. Second Edition. Éditions Ellipses, Paris.

Tabbibizar, R., Maisel, A., 2002. The impact of B-type natriuretic peptide levels on the diagnoses and management of congestive heart failure. Curr. Opin. Cardiol. 17, 340-345.

Takimoto, E., Champion, H. C., Belardi, D., Moslehi, J., Mongillo, M., Mergia, E., Montrose, D. C., Isoda, T., Aufiero, K., Zaccolo, M., Dostmann, W. R., Smith, C. J. \& Kass, D. A., 2005a. cGMP catabolism by phosphodiesterase $5 \mathrm{~A}$ regulates cardiac adrenergic stimulation by NOS3-dependent mechanism. Circ. Res. 96, 100-109. 
Takimoto, E., Champion, H. C., Li, M., Belardi, D., Ren, S., Rodriguez, E. R., Bedja, D., Gabrielson, K. L., Wang, Y. \& Kass, D. A., 2005. Chronic inhibition of cyclic GMP phosphodiesterase 5A prevents and reverses cardiac hypertrophy. Nat. Med. 11, 214-22.

Tokudome, T., Horio, T., Soeki, T., Mori, K., Kishimoto, I., Suga, S., Yoshihara, F., Kawano, Y., Kohno, M., Kangawa, K., 2004. Inhibitory effect of C-type natriuretic peptide (CNP) on cultured cardiac myocyte hypertrophy: interference between CNP and endothelin-1 signaling pathways. Endocrinology 145, 2131-2140.

van der Velden, J., Papp, Z., Zaremba, R., Boontje, N. M., deJong, J. W., Owen, V. J., Burton, P. B. J., Goldmann, P., Jaquet, K., Stienen, G. J. M., 2003. Increased $\mathrm{Ca}^{2+}$-sensitivity of the contractile apparatus in end-stage human heart failure results from altered phosphorylation of contractile proteins. Cardiovasc. Res. 57, 37-47.

Vandecasteele, G., Eschenhagen, T., Fischmeister, R., 1998. Role of the NO-cGMP pathway in the muscarinic regulation of the L-type $\mathrm{Ca}^{2+}$ current in human atrial myocytes. J. Physiol. $506,653-663$.

Vandecasteele, G., Eschenhagen, T., Scholz, H., Stein, B., Verde, I., Fischmeister, R., 1999. Muscarinic and $\beta$-adrenergic regulation of heart rate, force of contraction and calcium current is preserved in mice lacking endothelial nitric oxide synthase. Nat. Med. 5, 331-334.

Vandecasteele, G., Verde, I., Rucker-Martin, C., Donzeau-Gouge, P., Fischmeister, R., 2001. Cyclic GMP regulation of the L-type $\mathrm{Ca}^{2+}$ channel current in human atrial myocytes. J. Physiol. 533, 329-340.

Verde, I., Vandecasteele, G., Lezoualc'h, F., Fischmeister, R., 1999. Characterization of the cyclic nucleotide phosphodiesterase subtypes involved in the regulation of the L-type $\mathrm{Ca}^{2+}$ current in rat ventricular myocytes. Br. J. Pharmacol. 127, 65-74. 
Wang, Y. G., Wagner, M. B., Joyner, R. W. \& Kumar, R., 2000. cGMP-dependent protein kinase mediates stimulation of L-type calcium current by cGMP in rabbit atrial cells. Cardiovasc. Res. 48, 310-322.

Wegener, J. W., Nawrath, H., Wolfsgruber, W., Kuhbandner, S., Werner, C., Hofmann, F., Feil, R., 2002. cGMP-dependent protein kinase I mediates the negative inotropic effect of cGMP in the murine myocardium. Circ. Res. 90, 18-20.

Xiao, R. P., Zhu, W., Zheng, M., Chakir, K., Bond, R., Lakatta, E. G., Cheng, H., 2004.

Subtype-specific beta-adrenoceptor signaling pathways in the heart and their potential clinical implications. Trends Pharmacol. Sci. 25, 358-365.

Zaccolo, M., De Giorgi, F., Cho, C. Y., Feng, L., Knapp, T., Negulescu, P. A., Taylor, S. S., Tsien, R. Y., Pozzan, T., 2000. A genetically encoded, fluorescent indicator for cyclic AMP in living cells. Nat. Cell Biol. 2, 25-29.

Ziolo, M. T., Katoh, H., Bers, D. M., 2001. Expression of inducible nitric oxide synthase depresses beta-adrenergic-stimulated calcium release from the sarcoplasmic reticulum in intact ventricular myocytes. Circulation 104, 2961-2966. 